\title{
Gambaran Lama Waktu Pelepasan Plasenta dengan Manajemen Aktif Kala III dan Masase Fundus Setelah Bayi Lahir di Rsud Kelas B Kabupaten Subang
}

\author{
Euis Sisca Alviani', Merry Wijaya², Irna Kurnia² \\ ${ }^{1}$ Dinas Kesehatan Kabupaten Bandung Barat \\ ${ }^{2}$ Departemen Ilmu Kesehatan Masyarakat, Fakultas Kedokteran Universitas Padjadjaran
}

\begin{abstract}
Abstrak
Penyebab AKI di Indonesia yaitu perdarahan saat persalinan, MAK III terbukti mengurangi perdarahan, MAK III yaitu suntik oksitosin 1 menit setelah bayi lahir ketika tidak ada janin ke dua, penegangan tali pusat terkendali, masase fundus uteri setelah plasenta lahir, dengan MAK III dapat mengurangi perdarahan namun, penelitian lain menyebutkan masase fundus uteri sebelum plasenta lahir dapat mengurangi kehilangan darah, waktu pengeluaran plasenta berpengaruh terhadap pengeluaran darah. Penelitian ini bertujuan mengetahui lamanya waktu pelepasan plasenta dengan MAK III dan masase fundus uteri setelah bayi lahir di RSUD Subang. Metode yang digunakan adalah metode penelitian deskriptif dengan pendekatan secara Cross Sectional. Pengambilan sampel menggunakan accidental sampling sebanyak $66 \mathrm{ibu}$ bersalin di RSUD Subang dengan menggunakan lembar observasi dan dilaksanakan pada 29 April - 3 Juli 2015. Hasil penelitian diperoleh gambaran lama waktu pelepasan plasenta dengan MAK III dari 33 responden 87,9\% dan 33 responden masase fundus uteri 81,8\% terbanyak dalam waktu $<15$ menit untuk usia, paritas yang dilakukan dengan MAK III $<15$ menit adalah usia 20-35 tahun 60,6\% dan 2-4 (multipara) 48,4\% untuk masase 20-35 tahun 36,3\% dan 1 (primipara) 54,5\%. Simpulan dari penelitian adalah lama pelepasan plasenta dengan MAK III dan masase fundus uteri setelah bayi lahir terbanyak $<15$ menit.
\end{abstract}

Kata Kunci : Manajemen Aktif Kala III, Masase fundus uteri, Pelepasan Plasenta, Waktu

\section{Overview Time Delivery of Placenta with Active Management of the Third and Massage the Fundus Before Placenta Delivery in Rsud Class B Subang}

\begin{abstract}
Highest cause of maternal death in Indonesia is haemorrage, delivery placenta is a state of risk. Active management of the third for preventing postpartum haemorrhage. Active management of the third injecting oxytosin 1 minutes after birth when there is no fetus to two, controlled cord traction, massage the fundus uterus after delivery of the placenta. However, other research said that uterine massage before placenta delivery can prevent postpartum haemorrhage. Time delivery of the placenta affects the amount of blood loss. This study aims to describe how long of placenta delivery using active management of the third and massage after birth and before placenta delivery RSUD Subang. The method used in this research is descriptive cross sectional approach. The sampling technique used accidental sampling as 66 inpatu in RSUD Subang using observation sheet in periode 29 April - 3 Juli 2015. The results of this research, descriptive time delivery of placenta with active management of the third 33 responden is $87,9 \%$ and 33 responden massage the fundus before placenta delivery is $81,8 \%$ highest in $<15$ minutes, for age and parity by MAK III <15 minutes was 20-35 years 60,6\% and 2-4 (multiparity) 48,4\% for massage 20-35 years $36,3 \%$ and 1 (primiparity) 54,5\%. The conclusion of this research that the majority of time range of placenta delivery using management of the third and massage after birth and before delivery of the placenta is $<15$ minutes.
\end{abstract}

Keyword : Active management of the third, massage fundus, Placenta Delivery, Time

Korespondensi:

Euis Sisca Alviani

Fakultas Kedokteran Universitas Padjadjaran

Jl. Raya Bandung-Sumedang KM 21 Jatinangor, Sumedang

Mobile : 085295328808

Email : euissiscats31@gmail.com 


\section{Pendahuluan}

Angka Kematian Ibu (AKI) merupakan salah satu indikator untuk melihat derajat kesehatan perempuan. AKI juga merupakan salah satu target yang ditentukan dalam tujuan pembangunan millenium yaitu tujuan ke 5 untuk meningkatkan kesehatan ibu, dimana target yang akan dicapai sampai tahun 2015 adalah mengurangi sampai $3 / 4$ risiko jumlah kematian ibu. Departemen kesehatan sendiri menargetkan AKI pada tahun 2010 sekitar 226 orang dan pada tahun 2015 menjadi 102 orang per tahun. ${ }^{1,2}$

Penyebab kematian maternal tertinggi di Indonesia adalah perdarahan, infeksi dan toxemia gravidarum. Berdasarkan Survei Demografi dan Kesehatan Indonesia (SDKI) tahun 2012 angka kematian maternal mencapai 359 per 100.000 kelahiran hidup, jumlah ini meningkat dibandingkan SDKI tahun 2007 yaitu 228 per100.000 kelahiran hidup dan perdarahan merupakan penyebab kematian utama, keadaan tersebut dapat di karenakan atonia uteri (kegagalan rahim untuk berkontraksi dengan baik setelah melahirkan), trauma (serviks, vagina, atau laserasi perineum), perlekatan plasenta, gangguan pembekuan darah, inversio uterus. ${ }^{2}$ Namun pada umumnya terjadi di karenakan kelemahan atau tidak adanya kontraksi uterus (atonia uteri) sebanyak $75-90 \% 0^{2,3}$

Mengingatperan bidan sangatbesar, khususnya dalam upaya peningkatan derajat kesehatan ibu dan anak, keberadaan bidan merupakan salah satu tolak ukur kesehatan. Asuhan kebidanan pada ibu bersalin merupakan salah satu kompetensi utama bidan, oleh karena itu seluruh bidan diharapkan dapat melaksanakan tugasnya secara profesional dan berkualitas dengan penguasaan ilmu pengetahuan dan keterampilan, tanggap terhadap masalah, serta mampu memenuhi kebutuhan ibu dan bayi. ${ }^{1}$ Persalinan merupakan proses pengeluaran hasil konsepsi dimulai dari kontraksi persalinan sejati, yang dapat merubah serviks secara progresif dan berakhir oleh pengeluaran plasenta. ${ }^{1,2,4}$ Tahap persalinan dibagi menjadi 4 kala, yaitu kala 1 persalinan yang dimulai sejak adanya his sejati yang menyebabkan pembukaan pada serviks hingga pembukaan lengkap, kala 2 persalinan dimulai dari pembukaan lengkap hingga lahirnya bayi, kala 3 persalinan dimulai setelah bayi lahir dan berakhir dengan lahirnya plasenta serta selaput ketuban yang biasanya lepas dalam 5-15 menit setelah bayi lahir, kala 4 persalinan dimulai setelah lahirnya plasenta sampai 2 jam post partum. ${ }^{1,2,5}$ Kehilangan darah dengan cepat terjadi setelah kelahiran bayi karena pemisahan plasenta, periode tersebut merupakan periode berisiko karena rahim tidak berkontraksi dengan baik setelah lahirnya bayi. Pelepasan plasenta terjadi karena adanya pergeseran dari permukaan plasenta saat rahim berkontraksi setelah bayi dilahirkan. ${ }^{2}$ Manajemen Aktif Kala III (MAK III) terbukti dapat mengurangi kejadian perdarahan pasca persalinan namun, tidak jarang dapat terjadi kesalahan dalam penanganan kala III persalinan sehingga pelepasan plasenta lebih lama, faktor lain yang dapat memengaruhi waktu pelepasan plasenta yaitu usia kurang dari 20 tahun atau lebih dari 35 tahun, grande multipara dapat mengakibatkan kelahiran plasenta terjadi lebih lambat hingga terjadi retensio plasenta (plasenta tidak lahir lebih dari 30 menit) dan memperbanyak jumlah darah yang keluar., ${ }^{2,6}$

MAK III atau Active Management of the third Stage of labor didefinisikan sebagai pemberian intramuskular $10 \mathrm{IU}$ oksitosin setelah bayi lahir dan ketika tidak ada janin ke dua di paha kanan anterolateral dan melakukan jepit potong tali pusat, Penegangan Tali pusat Terkendali (PTT) atau Controlled Cord Traction (CCT) setelah ada kontraksi sehingga terdapat tanda pelepasan plasenta yaitu semburan darah, uterus globuler, tali pusat memanjang dan masase fundus setelah melahirkan plasenta. $1,3,7$

Dari empat uji klinis berdasarkan fasilitas menunjukkan penurunan $62 \%$ risiko Post Partum Haemorrhage terkait dengan MAK III. World Health Organization (WHO), International Federation of Gynecologists and Obstetricians (FIGO) dan International Confederation of Midwives (ICM) merekomendasikan bahwa bidan terampil menyediakan Manajemen Aktif Kala III untuk semua kelahiran vagina. Menyarankan oksitosin (10 IU) atau misoprostol (400-600 mcg per oral) harus diberikan oleh tenaga kesehatan terlatih dalam penggunaannya untuk mencegah Post Partum Haemorrhage. ${ }^{3}$

Pada saat peneliti melaksanakan Praktik di Ruang BersalinRSUD KelasB Kabupaten Subang, terdapat perbedaan mengenai cara pengeluaran plasenta karena beberapa penolong melakukan masase fundus uteri sebelum plasenta lahir, menurut penolong tindakan tersebut dilakukan agar menghasilkan kontraksi, keadaan tersebut sejalan dengan penelitian yang melakukan pijat rahim sebelum dan setelah melahirkan plasenta, dengan merekrut 1964 perempuan di Mesir dan Afrika Selatan. Perempuan yang diberikan oksitosin, pijat rahim atau keduanya setelah melahirkan bayi sebelum pengeluaran plasenta. Tidak ada manfaat tambahan untuk pijat rahim ditambah oksitosin dalam hal kehilangan darah lebih besar dari atau sama dengan $500 \mathrm{~mL}$ atau untuk penggunaan tambahan uterotonika dan pada kelompok yang diberikan masase uterus terdapat 1 kasus plasenta tidak lahir dalam 30 menit. 
Dapat disimpulkan pada penelitian tersebut yaitu masase uterus kurang efektif daripada oksitosin saja atau masase ditambah oksitosin..$^{8,10}$

Pada penelitian tersebut, perempuan yang dilakukan masase uterus akan diberikan 10 IU oksitosin intramuskular segera setelah melahirkan. Tali pusat akan dijepit dan dipotong sekitar 1 menit setelah melahirkan bayi. Fundus uteri digosok dengan gerakan berulang yang stabil dan tegas setelah itu melakukan penegangan tali pusat terkendali untuk melahirkan plasenta. ${ }^{8,11}$

Berdasarkan latar belakang di atas peneliti tertarik untuk meneliti yaitu gambaran lama waktu pelepasan plasenta dengan Manajemen Aktif Kala III dan masase fundus setelah bayi lahir di Ruang Bersalin RSUD Kelas B Kabupaten Subang tahun 2015.

\section{Metode}

Penelitian ini menggunakan penelitian deskriptif yang dilakukan secara observasi dengan pendekatan secara cross sectional. Populasi dalam penelitian ini adalah ibu yang melahirkan pervaginam baik dengan letak sungsang maupun letak kepala, baik dengan induksi maupun tidak, yang datang pada saat kala I maupun II dengan tidak ada riwayat SC (Sectio Caesaria), pengambilan data yang dilaksanakan pada tanggal 29 April 3 Juli 2015 di Ruang Bersalin RSUD Kelas B Kabupaten Subang yang berjumlah $193 \mathrm{ibu}$ bersalin. Metode sample yang digunakan dalam penelitian ini adalah nonprobability sampling dan teknik sampel yang digunakan adalah accidental sampling, dengan sampel minimal didapatkan 66 responden. Variabel dalam penelitian ini adalah lama waktu pengeluaran plasenta dengan menggunakan MAK III serta masase fundus uteri sebelum plasenta lahir berdasarkan usia dan paritas ibu. Data yang dikumpulkan pada penelitian ini dengan menggunakan data primer yang dilakukan secara observasi dengan melihat durasi lamanya kala III persalinan, yaitu ibu yang melahirkan pervaginam baik letak sungsang maupun letak kepala, baik dengan induksi maupun tidak, dengan meminta persetujuan responden dan menentukan pasien yang diberikan MAK III atau masase fundus setelah bayi lahir menggunakan lembar observasi, bila tidak sesuai dengan kriteria inklusi atau data kurang maka data tersebut tidak dipakai. Setelah semua data terkumpul, maka peneliti melakukan pengolahan data melalui beberapa tahap yaitu memeriksa ketepatan dan kelengkapan data. Data yang telah terkumpul dikoreksi ketepatan dan kelengkapannya, kemudian dimasukkan kedalam program komputer. Data disajikan dalam bentuk distribusi frekuensi. Analasis data yang digunakan pada penelitian ini adalah univariat. Analisis univariat dalam penelitian ini dilakukan untuk mengetahui dan mendapatkan hasil terhadap gambaran lama waktu pelepasan plasenta dengan MAK III dan masase fundus uteri.

\section{Hasil}

Dari tabel 1 dapat dilihat bahwa lamanya kala III persalinan dengan MAK III dan dengan masase fundus uteri terbanyak adalah $<15$ menit sebanyak 29 responden dan dengan masase fundus uteri sebanyak 27 responden.

Dari tabel 2 dapat dilihat bahwa usia terbanyak pada seluruh responden yaitu 20-35 tahun sebanyak 38 responden dan paritas terbanyak pada seluruh responden yaitu 2 (2-4 (multipara)) sebanyak 33 responden.

Dari tabel 3 bahwa hasil terbanyak lamanya pelepasan plasenta dengan MAK III berdasarkan usia yaitu usia 20-35 tahun sebanyak 20 responden dengan lama waktu pelepasan plasenta $<15$ menit.

Dari tabel 4 bahwa hasil terbanyak lamanya pelepasan plasenta dengan MAK III berdasarkan paritas yaitu 2-4 (multipara) sebanyak 16 responden dengan lama waktu pelepasan plasenta $<15$ menit.

Dari tabel 5 bahwa hasil terbanyak lamanya pelepasan plasenta dengan masase fundus uteri berdasarkan usia ibu yaitu 20-35 tahun 12 responden dengan lama waktu pelepasan plasenta $<15$ menit.

Dari tabel 6 bahwa hasil terbanyak lamanya pelepasan plasenta dengan masase fundus uteri berdasarkan paritas ibu yaitu 1 (primipara) sebanyak 18 responden dengan lama waktu pelepasan plasenta $<15$ menit.

Tabel 1 Distribusi Frekuensi Lama Pelepasan Plasenta dengan MAK III dan Masase Fundus Uteri

\begin{tabular}{|c|c|c|c|c|c|c|c|c|c|}
\hline \multirow[t]{3}{*}{ No } & \multirow{3}{*}{$\begin{array}{c}\text { Pengeluaran } \\
\text { Plasenta }\end{array}$} & \multicolumn{6}{|c|}{ Lamanya Kala III Persalinan } & \multicolumn{2}{|c|}{ Jumlah } \\
\hline & & \multicolumn{2}{|c|}{$<15$ menit } & \multicolumn{2}{|c|}{ 15-30 menit } & \multicolumn{2}{|c|}{$>30$ menit } & \multirow[t]{2}{*}{$\mathbf{n}$} & \multirow[t]{2}{*}{$\%$} \\
\hline & & f & $\%$ & $\mathbf{f}$ & $\%$ & f & $\%$ & & \\
\hline 1. & MAK III & 29 & 87,9 & 4 & 12,1 & 0 & 0 & 33 & 100 \\
\hline 2. & Masase Fundus Uteri & 27 & 81,8 & 4 & 12,1 & 2 & 6,1 & 33 & 100 \\
\hline
\end{tabular}


Euis Sisca Alviani : Gambaran Lama Waktu Pelepasan Plasenta dengan ManajSemen Aktif Kala III dan Masase Fundus Setelah Bayi Lahir di Rsud Kelas B Kabupaten Subang

Tabel 2 Distribusi Frekuensi Karakteristik Responden

\begin{tabular}{|c|c|c|c|}
\hline No & Karakteristik & f & $\%$ \\
\hline \multirow[t]{4}{*}{1} & Usia (Tahun) & & \\
\hline & $1(<20)$ & 18 & 27,3 \\
\hline & $2(20-35)$ & 38 & 57,5 \\
\hline & $3(>35)$ & 10 & 15,2 \\
\hline \multirow[t]{5}{*}{2} & Paritas & & \\
\hline & 1 (1 (Primipara) $)$ & 32 & 48,5 \\
\hline & $2(2-4($ Multipara $))$ & 33 & 50 \\
\hline & 3 (>4 (Grandemultipara) $)$ & 1 & 1,5 \\
\hline & Total & 66 & 100 \\
\hline
\end{tabular}

Tabel 3 Distribusi Frekuensi Pelepasan Plasenta dengan MAK III Berdasarkan Usia Ibu

\begin{tabular}{|c|c|c|c|c|c|c|c|c|}
\hline \multirow[t]{3}{*}{ Usia (Tahun) } & \multicolumn{6}{|c|}{ Lamanya Pelepasan Plasenta } & \multicolumn{2}{|c|}{ Jumlah } \\
\hline & \multicolumn{2}{|c|}{$<15$ menit } & \multicolumn{2}{|c|}{ 15-30 menit } & \multicolumn{2}{|c|}{$>30$ menit } & \multirow[t]{2}{*}{$\mathrm{n}$} & \multirow[t]{2}{*}{$\%$} \\
\hline & f & $\%$ & f & $\%$ & f & $\%$ & & \\
\hline$<20$ & 7 & 21,21 & 0 & 0 & 0 & 0 & 7 & 21,21 \\
\hline $20-35$ & 20 & 60,60 & 3 & 9,09 & 0 & 0 & 23 & 69,69 \\
\hline$>35$ & 2 & 6,06 & 1 & 3,03 & 0 & 0 & 3 & 9,09 \\
\hline Total & & & & & & & 33 & 100 \\
\hline
\end{tabular}

Tabel 4 Distribusi Frekuensi Pelepasan Plasenta dengan MAK III Berdasarkan Paritas Ibu

\begin{tabular}{|c|c|c|c|c|c|c|c|c|}
\hline \multirow{3}{*}{ Paritas } & \multicolumn{6}{|c|}{ Lamanya Pelepasan Plasenta } & \multicolumn{2}{|c|}{ Jumlah } \\
\hline & \multicolumn{2}{|c|}{$<15$ menit } & \multicolumn{2}{|c|}{ 15-30 menit } & \multicolumn{2}{|c|}{$>\mathbf{3 0}$ menit } & \multirow[t]{2}{*}{$\mathbf{n}$} & \multirow[t]{2}{*}{$\%$} \\
\hline & f & $\%$ & f & $\%$ & f & $\%$ & & \\
\hline 1 (Primipara) & 13 & 39,39 & 1 & 3 & 0 & 0 & 14 & 42,39 \\
\hline 2-4 (Multipara) & 16 & 48,48 & 3 & 9 & 0 & 0 & 19 & 57,48 \\
\hline$>4$ (Grandemultipara) & 0 & 0 & 0 & 0 & 0 & 0 & 0 & 0 \\
\hline Total & & & & & & & 33 & 100 \\
\hline
\end{tabular}

Tabel 5 Distribusi Frekuensi Pelepasan Plasenta dengan Masase Fundus Uteri Berdasarkan Usia Ibu

\begin{tabular}{|c|c|c|c|c|c|c|c|c|}
\hline \multirow[t]{3}{*}{ Usia (Tahun) } & \multicolumn{6}{|c|}{ Lamanya Pelepasan Plasenta } & \multicolumn{2}{|c|}{ Jumlah } \\
\hline & \multicolumn{2}{|c|}{$<15$ menit } & \multicolumn{2}{|c|}{ 15-30 menit } & \multicolumn{2}{|c|}{$>30$ menit } & \multirow[t]{2}{*}{$\mathbf{n}$} & \multirow[t]{2}{*}{$\%$} \\
\hline & f & $\%$ & f & $\%$ & f & $\%$ & & \\
\hline$<20$ & 11 & 33,33 & 0 & 0 & 0 & 0 & 11 & 33,33 \\
\hline $20-35$ & 12 & 36,36 & 1 & 3,03 & 2 & 6,06 & 15 & 45,45 \\
\hline$>35$ & 4 & 12,12 & 3 & 9,09 & 0 & 0 & 7 & 21,21 \\
\hline Total & & & & & & & 33 & 100 \\
\hline
\end{tabular}


Euis Sisca Alviani : Gambaran Lama Waktu Pelepasan Plasenta dengan Manajemen Aktif Kala III dan Masase Fundus Setelah Bayi Lahir di Rsud Kelas B Kabupaten Subang

Tabel 6 Distribusi Frekuensi Pelepasan Plasenta dengan Masase Fundus Uteri Berdasarkan Paritas Ibu

\begin{tabular}{|c|c|c|c|c|c|c|c|c|}
\hline \multirow{3}{*}{ Paritas } & \multicolumn{6}{|c|}{ Lamanya Pelepasan Plasenta } & \multicolumn{2}{|c|}{ Jumlah } \\
\hline & \multicolumn{2}{|c|}{$<15$ menit } & \multicolumn{2}{|c|}{ 15-30 menit } & \multicolumn{2}{|c|}{$>30$ menit } & \multirow[t]{2}{*}{$\mathbf{n}$} & \multirow[t]{2}{*}{$\%$} \\
\hline & f & $\%$ & f & $\%$ & f & $\%$ & & \\
\hline 1 (Primipara) & 18 & 54,54 & 0 & 0 & 0 & 0 & 18 & 54,54 \\
\hline 2-4 (Multipara) & 9 & 27,27 & 3 & 9,09 & 2 & 6,06 & 14 & 42,42 \\
\hline$>4($ Grandemultipara $)$ & 0 & 0 & 1 & 3,03 & 0 & 0 & 1 & 3,03 \\
\hline Total & & & & & & & 33 & 100 \\
\hline
\end{tabular}

\section{Pembahasan}

Berdasarkan waktu yang diperlukan dapat dilihat dari tabel 1 bahwa kala III persalinan dengan MAK III (Manajemen Aktif Kala III) sebelum plasenta lahir terbanyak $<15$ menit yaitu sebanyak 29 responden dari 33 responden, dan dari hasil pengolahan data menunjukkan rata-rata lamanya waktu pelepasan plasenta yaitu 6,54 menit. Dapat dilihat pula pada tabel 1 bahwa lamanya kala III persalinan dengan masase fundus uteri setelah bayi lahir yaitu $<15$ menit sebanyak 27 responden dari 33 responden, dan dari hasil pengolahan data menunjukkan rata-rata lamanya waktu pelepasan plasenta yaitu 10,75 menit dan pada masase fundus terdapat kejadian retensio plasenta (plasenta tidak lahir dalam 30 menit) sebanyak 2 responden dan untuk membantu melahirkan plasenta dengan cara manual plasenta.

Menurut teori rata-rata waktu pelepasan plasenta adalah 5-15 menit. Namun, itu adalah kisaran normal untuk tahap persalinan plasenta, risiko perdarahan meningkat ketika kala III lebih dari 30 menit terutama antara 30 dan 60 menit. ${ }^{4}$ Namun, bila kala III melebihi 15 menit maka penggunaan uterotonika dapat diberikan untuk membantu pengeluaran plasenta. Tempat perlekatan plasenta menentukan kecepatan pemisahan dan metode ekspulsi plasenta. ${ }^{1}$

Pada penelitian ini waktu terbanyak yaitu $<15$ menit keadaan tersebut merupakan keadaan normal. Lama rata-rata waktu yang dibutuhkan tidak berbeda jauh, namun teknik masase fundus uteri lebih lama yaitu 4,21 menit. Menurut teori hal tersebut terjadi dapat di karenakan penolong melakukan penambahan tindakan yaitu dengan melakukan masase dibandingkan dengan MAK III yang tanpa melakukan masase, karena hanya mengecek fundus untuk menentukan ada tidaknya kontraksi.

Menurut penelitian yang pernah dilakukan sebelumnya tahun 2011, masase fundus sebelum plasenta lahir dapat mengakibatkan leher rahim menutup dan plasenta terperangkap didalam, sehingga pelepasan plasenta lebih lama dan risiko perdarahan meningkat. ${ }^{12,13}$ Namun penelitian lain yaitu Revinel tahun 2014 menyebutkan bahwa pijat rahim selama dan setelah melahirkan plasenta efektif dalam mengurangi kehilangan darah. $^{2}$

Namun, penelitian yang dilakukan oleh Abdel H, Singata M, Abdel M, dkk tahun 2010 menyebutkan bahwa penggunaan pijat rahim sebelum dan setelah melahirkan plasenta tidak ada manfaat tambahan, untuk pijat rahim ditambah oksitosin dalam hal kehilangan darah lebih besar dari atau sama dengan $500 \mathrm{~mL}$ atau untuk penggunaan tambahan uterotonika dan pada kelompok yang diberikan masase uterus terdapat 1 kasus plasenta tidak lahir dalam 30 menit. Dapat disimpulkan pada penelitian tersebut yaitu masase uterus kurang efektif daripada oksitosin saja atau masase ditambah oksitosin. ${ }^{7}$

Pelepasan plasenta dengan masase dapat merangsang kontraksi maka dari itu dari hasil penelitian sebelumnya yang dilakukan oleh Hofmeyr GJ, Abdel Aleem H, Abdel Aleem MA tahun 2013 dan Abdel H, Singata M, Abdel M, dkk tahun 2010, pelepasan plasenta dengan masase dapat dilakukan ketika uterotonika tidak tersedia karena dapat mencegah kehilangan darah berkelanjutan. ${ }^{7,9}$ Masase fundus juga diberikan karena oksitosin dapat bereaksi ketika 2-3 menit setelah pemberian oksitosin maka dari itu masase dapat merangsang kontraksi dan kinerja dari pemberian oksitosin. ${ }^{2}$

Dari hasil penelitian ini didapatkan ibu yang diberikan masase fundus uteri merasakan kurang nyaman dan tidak jarang merasakan mual, keadaan tersebut sesuai dengan penelitian yang pernah dilakukan sebelumnya yang dilakukan oleh Abdel H, Singata M, Abdel M, dkk tahun 2010. ${ }^{8}$ Untuk pelepasan plasenta MAK III dipercaya dapat mempersingkat waktu pelepasan plasenta sehingga dapat menurunkan AKI (Angka Kematian Ibu) yang diakibatkan oleh perdarahan. Dalam melakukan MAK III yang perlu diperhatikan yaitu teknik yang dilakukan dan ketersediaan uterotonika sehingga pelepasan plasenta berjalan dengan aman. 
Berdasarkan hasil penelitian yang terdapat pada tabel 3 distribusi frekuensi pelepasan plasenta dengan MAK III berdasarkan usia ibu sebagian besar (60,60\%) yaitu usia 20-35 dengan lama pelepasan plasenta $<15$ menit. Sedangkan pada tabel 5 distribusi frekuensi pelepasan plasenta dengan masase fundus uteri berdasarkan usia ibu sebagian besar (36,36\%) yaitu usia 20-35 tahun dengan lama pelepasan plasenta $<15$ menit.

Jika dilihat pada tabel 3 dari lama pelepasan plasenta dengan MAK III berdasarkan usia untuk 15-30 menit usia 20-35 tahun sebanyak 9,09\% dan untuk $>30$ menit tidak ada. Pada tabel 5 lama pelepasan plasenta dengan masase fundus uteri berdasarkan usia untuk 15-30 menit usia >35 tahun sebanyak $9,09 \%$ dan $>30$ menit usia $20-35$ tahun sebanyak $6,06 \%$ pada pelepasan plasenta $>30$ menit maka dilakukan manual plasenta. Dapat disimpulkan hasil tersebut hampir sama, baik dengan MAK III maupun masase fundus uteri. Usia ibu yang berisiko adalah $<20$ tahun dan $>35$ tahun pada persalinan $<20$ tahun organ reproduksi ibu masih belum sempurna sedangkan pada usia $>35$ tahun sudah mengalami penurunan fungsi. ${ }^{1,4}$

Menurut penelitian yang dilakukan oleh Kostania Gita, Eka Desty Purnamasari tahun 2011 faktor usia merupakan faktor penyulit atau salah satu faktor yang memengaruhi prognosis persalinan, terutama pada wanita kelompok usia lebih dari 35 tahun, sehingga dapat memengaruhi lamanya pelepasan plasenta. ${ }^{14}$

Usia lebih tua dapat mengakibatkan penurunan yang progresif dari endometrium sehingga untuk mencukupi kebutuhan nutrisi janin diperlukan pertumbuhan plasenta yang lebih luas, dan mengadakan perluasan implantasi dan villi khorialis menembus dinding uterus lebih dalam lagi sehingga pelepasan plasenta lebih lama dan risiko terhadap kejadian retensio plasenta.

Namun pada penelitian ini usia ibu tidak berbeda lamanya pelepasan plasenta baik dilakukan dengan masase maupun MAK III, namun pada masase terdapat retensio plasenta dimana plasenta tidak lahir dalam 30 menit sehingga dilakukannya manual plasenta, keadaan tersebut terjadi pada responden yang termasuk dalam usia reproduksi yaitu 20-35 tahun keadaan tersebut tidak sesuai dengan teori karena dapat dipengaruhi oleh kinerja oksitosin yang tidak dapat dilihat berdasarkan usia atau paritas ibu, kerja oksitosin itu sendiri dikarenakan terdapat reseptor oksitosin pada membran sel otot polos sehingga dapat merangsang pelepasan sel yang akan menyebabkan kontraksi uterus. ${ }^{2,9}$

Berdasarkan hasil penelitian yang terdapat pada tabel 4 distribusi frekuensi pelepasan plasenta dengan MAK III berdasarkan paritas ibu bersalin sebagian besar $(48,48 \%)$ yaitu $2-4$ (multipara) dengan lama pelepasan plasenta $<15$ menit. Pada tabel 6 distribusi frekuensi pelepasan plasenta dengan masase berdasarkan paritas ibu bersalin sebagian besar pada primipara sebanyak $(54,54 \%)$ dengan lama pelepasan plasenta $<15$ menit.

Jika dilihat pada tabel 4 dari lamanya pelepasan plasenta dengan MAK III untuk 15-30 menit sebagian besar $(9 \%)$ yaitu multipara dan pada tabel 6 dengan masase fundus uteri 15-30 menit sebagian besar $(9.09 \%$ ) yaitu 2-4 (multipara) dan grademultipara $(3,03 \%)$ untuk $>30$ menit yaitu multipara $(6,06 \%)$.

Menurut Kotania Gita, Eka Desty Purnamasari tahun 2011 faktor usia merupakan faktor predisposisi lainnya yaitu paritas dan usia di mana pada grandemultipara akan terjadi kemunduran dan kecacatan pada endometrium yang mengakibatkan terjadinya fibrosis pada bekas implantasi plasenta pada persalinan sebelumnya, sehingga vaskularisasi menjadi berkurang. ${ }^{14}$

Disimpulkan bahwa, lama pelepasan plasenta dengan MAK III dan masase fundus uteri setelah bayi lahir terbanyak $<15$ menit. Pada penelitian ini paritas multipara mengalami retensio plasenta sehingga pelepasan plasenta dilakukan dengan cara manual plasenta. Keterbatasan peneliti dalam penilitian ini yaitu, kurangnya waktu penelitian sehingga responden yang didapatkan tidak banyak dan penelitian ini dapat dikembangkan dengan melihat apakah ada efek samping yang terjadi bila tindakan tersebut dilakukan apakah berhubungan dengan jumlah darah yang keluar atau tidak.

\section{Daftar Pustaka}

1. Nurasiah A. Asuhan Persalinan Normal Bagi Bidan. Jakarta : Refika Aditama ; 2012.

2. Revinel. Perbandingan Efektivitas Persalinan Aktif Kala III Antara Pemberian Misoprostol Per Rektal dan Oksitosin Intramuskuler. Bandung : Universitas Padjadjaran ; 2014. Di unduh tanggal 2 Mei 2015.

3. WorldHealthOrganization.Recommendation for the Prevention of Postpartum

Haemorrhage. summary of results from a WHO technical consultation; 2007.

4. Varney H. Buku Ajar Kebidanan. 4 ed. Jakarta : EGC ; 2008.

5. Suryani. Hubungan Pengetahuan, Sikap, dan Perilaku Bidan dengan Manajemen Aktif Kala Tiga di Kecamatan Majenang Cilacap. Bandung : Universitas Padjadjaran ; 2012.

6. Sosa CG. Use of oxytocin During Early Stages of labor And Its Effect On Active 
Management of Third Stage of Labor. Am J Obstet Gynecol ; 2011.

7. Metin A, Lumbiganon P, Landoulsi S, dkk. Active Management of The Third Stage of labour With and Without Controlled Cord Traction: a randomised, controlled, noninferiority trial ; 2012 ; 379. Di unduh tanggal 1 Mei 2015.

8. Abdel H, Singata M, Abdel M, dkk. Uterine Massage to Reduce Postpartum Hemorrhage After Vaginal Delivery. www.elsevier.com/ locate/ijgo, 17 April 2010:32-6. di unduh tanggal 10 Juni 2015.

9. Sadiq S. Prophylastic Use of Oxytocin (Syntocinon) vs Oxytocin Plus Ergometrine (Syntometrine) for Prevention of PPH. Pakistan journal of surgery ; 2008.

10. Hofmeyr GJ, Abdel Aleem H, Abdel Aleem MA. Uterine Massage for Preventing Postpartum Haemorrhage ; 2013. di unduh tanggal 10 Juni 2015.
11. Lebanon : Institutional Review Board. Effect of Uterine Massage Versus Sustained Uterine Compression On Blood Loss After Vaginal Delivery ; 2015.

12. PATH. Postpartum Haemorrhage ; 2011 ; Melalui: http://www.pphprevention.org/pph. php.

13. Prevention of Postpartum Hemorrhage Initiative. Prevention of Postpartum Haemorrhage: Implementing Active Management of the Third Stage ofLabor;2007.

14. Kostania Gita, Eka Desty Purnamasari. Hubungan Paritas dengan Lamanya Pelepasan Plasenta pada Ibu Bersalin di BPS Sarwo Endah. Manba'ul Ulum. Surakarta ; 2011. 